\title{
Non-R\&D Innovation and Innovation Performance: A Conceptual Framework
}

\author{
Widya Hastuti Afris \\ TeknikIndustri Agro Politeknik ATI Makassar \\ Email:widyah@atim.ac.id
}

(Diterima: 21 September 2020 ; direvisi: 22 September 2020; dipublikasikan 29 September 2020)

(C)2018 -Bongaya Journal of Research inManagement STIEM Bongaya. Ini adalah artikel dengan akses terbuka dibawah licenci CC BY-NC-4.0 (https://creativecommons.org/licenses/by-nc/4.0/ ).

\begin{abstract}
A number of studies in the innovation literature have examined the construct of $n o n-R \& D$ innovation. These research generally revealed a positive link between non- $R \& D$ innovation and innovation performance. As far as this paper is concerned, non-R\&D was specifically evaluated in the context of small and medium-sized enterprises (SMEs). An in-depth review of the extant literature was performed to develop a conceptual framework by exploring the major antecedents of non- $\& \& D$, the EO-non-R\&D innovationperformance relationship, and the key mediators and moderators of this relationship. This paper also examined several studies of SMEs with respect to various aspects of this framework in addition to providing suggestions for future research in order to understand more thoroughly on how non-R\&D influences SME innovation performance.
\end{abstract}

Keywords: firm-specific capability; entrepreneurial orientation; absorptive capacity; non$R \& D$ innovation]

\begin{abstract}
Abstrak: Sejumlah studi dalam literatur inovasi telah meneliti konstruk inovasi non-R\&D. Penelitian ini secara umum mengungkapkan hubungan positif antara inovasi non-R\&D dan kinerja inovasi. Pada makalah ini, non-PenelitiandanPengembangan secara khusus dievaluasi dalam konteks usaha kecil dan menengah (UKM). Sebuah tinjauan mendalam dari literatur yang ada dilakukan untuk mengembangkan kerangka konseptual dengan mengeksplorasi anteseden utama non-R\&D, hubungan inovasi-kinerja EO-non-R\&D, dan mediator kunci dan moderator dari hubungan ini. Makalah ini juga mengkaji beberapa studi UKM terkait dengan berbagai aspek kerangka kerja selain memberikan saran untuk penelitian selanjutnya agar dapat lebih memahami bagaimana pengaruh non-R\&D terhadap kinerja inovasi UKM.:
\end{abstract}

Kata kunci: Kemampuan spesifik perusahaan; Orientasi wirausaha; Kapasitas daya serap; Inovasi Non-R\&D

\section{INTRODUCTION}

In a general sense, research and development (R\&D) refers to the innovative activity that emphasises on aspects such as entrepreneurial orientation, innovation performance, and absorptive capacity as keys to organisational success [García-Sánchez, García-Morales, \& Martín-Rojas, 2018; Huda et al., 2019]. Although the R\&D-performance relationship has been the focus of many studies, efforts to synthesise existing findings to better understand this relationship in the context of smaller organisations have been virtually non-existent. Past research reflects some key differences 
between SMEs and larger organisations [Chamelian, 2016] and it is expected that the role of $R \& D$ in SMEs is quite distinct from that of larger organisations.

The primary objective of this paper is to formulate a conceptual framework to examine non-R\&D innovation in the context of SMEs. Such a framework allows better comprehension of the role of non-R\&D innovation and its influence on SME performance. The R\&D literature is used in this study to identify the constructs of particular relevance to SMEs. Increased emphasis is given to the antecedents of non-R\&D innovation as well as the mediators and moderators of the non-R\&D innovation-performance relationship. Following the discussion of the conceptual framework, this paper proceeds with the analysis of SME research in relation to the framework and offers suggestions for future research. Prior to the development of the conceptual framework, the subsequent section will examine the significance of the SME context for non-R\&D innovation.

\section{Non-R\&D Innovation}

Focusing in non-R\&D innovation, several studies offer dimension of non-R\&D innovation: technology adoption, imitation, minor modification, combining existing knowledge in new ways, and innovative marketing [Arundel et al., 2008; Huang et al., 2010; Guo et al., 2017] considering lack of resources and technologies in SMEs [Bala Subrahmanya, 2013]. Technology adoption as gaining external references on innovativeness of products and processes with little or no efforts. For instance, outsourcing spare part to other firms. Incremental change or minor modification is modifying products by purchasing products or processes or developing technology done by the firm itself. Imitation including reverse engineering refers to the replicating the previous existence of products or processes. Combining existing knowledge in new ways is set as knowledge of creating new products under tacit knowledge, engineering skills, and cumulative learning process that not exist in one specific firm but possibly flowing from informal contacts or highly skilled personnel movement into another firm. Among these four approaches of non-R\&D innovation, the least needed activity of creativeness is technology adoption rather than the others which need more innovative capabilities [Arundel et al., 2008].
Relates to the expenditure and budget allocation of innovation, Huang et al. (2010) studied in the empirical study utilizing the Third European Community Innovation Survey (CIS). Expenditures and its portion allocation of innovation in low-tech industries and lagged countries which have lower productive capacity and labour productivity need to increase their innovation budget to pursue innovativeness in such purchasing existing technology, incremental change or creativity to improve product and process. They suggested non-R\&D firms better have collaboration between firms, universities, and research institutes to acquire knowledge that support organizational decision of innovation strategy although some studies revealed weak linkage with public research labs and universities, such as Indian SMEs [Arora, 2011]. Still, collaboration as a source of indigenous knowledge is required by firms particularly local firms of developing countries relate to the modifying or diffusing technology [Intarakumnerd \& Schiller, 2009]. Hence, this study proposes additional non-R\&D dimension as R\&D collaborations.

\section{Absorptive Capacity (AC)}

In the macroeconomic study, concept of absorptive capacity firstly introduced as economic ability on utilizing and absorbing external information and resources [Adler, 1965]. Cohen \& Levinthal (1989) perceives this into steps of absorbing process within three dimensions of identifying, assimilating, and exploiting knowledge or "a firm's ability to create new knowledge" (p.570). These steps are directed to the individual capability in the organization. Further, the concept is redefined for commercial ends [Cohen \& Levinthal, 1990]. Regarding various organizational phenomena related to the absorptive capacity, Zahra \& George (2002) extended dimensions of absorptive capacity into knowledge acquisition and assimilation capabilities as sub dimensions of potential capacity (PACAP) and knowledge transformation and exploitation as part of realised capacity (RACAP). Later, large studies translate absorptive capacity as a component mechanism of organizational routine in the capability of a firm.

\section{Entrepreneurial Orientation (EO)}

In recent years, in the strategic management, there has been an increasing amount 
of literature on entrepreneurial orientation. The term of EO sometimes is associated with "Corporate Entrepreneurship" that directed to the operational of large firms [Burgelman, 1983] or "Intrapreneurship" for SMEs [Pinchot, 1985] but then argued by Bouchard \& Basso (2011) that the latter has significantly complex relates to the unit of analysis. At the firm level, this concept is viewed as an act entrepreneurially or the spirit of organizational entrepreneurship in pursuing business opportunities that potentially provide benefit [Lumpkin \& Dess, 1996]. Mostly, EO is directed to contribute on firm performance to investigate organizational phenomena [Zahra \& Covin, 1995; Wiklund \& Shepard, 2005] and shows its benefit to the firm in such improvement of revenue, empowerment, and profitability [Zahra, 1996]. In addition, this relationship is not limited to figure out on various perspective such as wealth creation of social capital [Stam \& Elfring, 2008]. Thus, some studies translate this concept into dimensions of complex phenomena, such as innovativeness, proactiveness and risk taking [Miller, 1983; Covin \& Slevin, 1989; 1991]; autonomy and competitive aggressiveness [Lumpkin \& Dess, 1996; Venkatraman, 1989].

\section{Innovation Performance (IP)}

Focusing on innovation which defines as "the implementation of a new or significantly improved product (good or service), or process, a new marketing method, or a new organizational method in business practices, workplace organisation or external relations [OECD, 2005:46]." The term of newness in innovation does not necessarily mean totally new creation but could be implementing new or improvement in particular firm or sector although not new in the industry. This follows the Oslo manual that emphasized "The minimum requirement for an innovation is that the product, process, marketing method or organisational method must be new (or significantly improved) to the firm. This includes products, processes and methods that firms are the first to develop and those that have been adopted from other firms or organisations" [OECD, 2005:46]. These encourage many researchers to measure the form of innovation into innovation performance.

Focusing in the low-technology industries with innovation is shaped differently from activities and behaviour of R\&D intensity occupied with advanced machinery or training, the result of non-R\&D activities is another interesting spot to explore due to merely as the users of generated innovation rather than the generator of innovation [Santamaría et al., 2009]. Notwithstanding, proactive SMEs possibly has high innovation performance as long as having external innovative relationships such as suppliers, users, or customers [Lasagni, 2012]. This is similar with diffusion of knowledge that improve know-how of technology adaption [Robertson \& Patel, 2007]. However, limited study to focus on innovation performance within firm's non-R\&D innovation of low-tech industries.

Table 1 presents the studies of non-R\&D and innovation performance in the past 5 years. Based on the review of existing literature, it was found that no research on non-R\&D innovation was conducted in the context of Indonesian firms in the past 5 years.

\section{METHODOLOGY}

The related previous studies are reviewed in this paper. Strategic management and innovation journals relate to the capability approach are explored to identify the influence role of non-R\&D within small firms sized development. Hence, more attention is put up on papers which merely focus on non-R\&D for innovation performance achievement. This paper utilized 12 academic journals which are oriented on sustainability, engineering, innovation, and strategic business.

Antecedents variable of non-R\&D Innovation for Innovation Performance to build a conceptual framework are excavated through systematic content analysis. Therefore, utilizing qustionnaire instrument is suggested to conduct quantitative research for data collection to strengthen the conceptual framework.

\section{DEVELOPMENT OF CONCEPTUAL MODEL AND PROPOSITIONS}

This section proposes the conceptual model of non-R\&D innovation, entrepreneurial orientation, absorptive capacity and innovation performance. Although existing literature suggested a number of important capabilities which can potentially affect the non-R\&D innovation-innovation performance relationship, academic discussions were typically concentrated on $R \& D$ innovation over non-R\&D innovation [Lopez-Rodriguez \& Martinez-Lopez, 2017]. As such, entrepreneurial orientation and absorptive capacity have been acknowledged as the internal 
capabilities of a firm. It should also be highlighted that the conceptual framework is consistent with dynamic capability approach [Teece et al., 1997] as the extension of the resource-based view.

The current study is fundamentally concerned with the capability of a firm to manage the integration of resources and activity as well as the capacity of internal and external knowledge into processes and activities of a dynamic approach. It should be highlighted that research of non-R\&D innovation is mostly based on firms' practice in Western or developed countries; only a few have addressed SMEs in developing countries such as Indonesia. Also, context specificity has been somewhat overlooked by empirical studies, such as the capability level when examining the relationship between different innovation activities and firm performance.

\section{Entrepreneurial Orientation and Non-R\&D Innovation}

Businesses are currently facing global competition with the high-level intensity of innovation alongside rapid technological advancement. This dynamic business environment impacts the management of an organisation as a result of complex operation technologies that involve the intensity of research and development on products and processes; on the contrary, not all industries are occupied with high technology [Covin et al., 1990]. Nevertheless, small firms are able to sustain in the dynamic environment through entrepreneurialtype strategies [Miller \& Toulouse, 1986]. Covin et al. (1990) revealed that firms of high and low technologies basically have a similar mode of competition with regard to growth-seeking strategies. Some studies suggested a highly flexible and rapid response to changes within the dynamic environments of technology-intense industry [e.g., Gomez-Mejia et al., 2014]. This condition resonates with Kuratko and Morris's work (2003) which has described that entrepreneurial ability is required to facilitate change and innovation, particularly in the global marketplace.

Additionally, prior studies have discovered that innovation success is positively influenced by entrepreneurial orientation [Parkman et al., 2012]. In an empirical study of SMEs conducted in Indonesia, Suyanto (2014) emphasised that the orientation of encouragement in the effort to initiate and ameliorate competition is crucial in improving innovation. This discovery is similar with the study of Spanish SMEs that was carried out by Martínez-Román and Romero (2017) in which it was found that motivation of entrepreneur as internal capabilities on technology adoption has a relevant factor on innovativeness. Therefore, the following proposition is deduced:

P1: There is a positive relationship between Entrepreneurial Orientation and non- $R \& D$ innovation

\section{The Moderating Role Of Absorptive Capacity} It has been noted that the investment of knowledge-based resources is essential for the improvement of innovation activities [Wang et al., 2014]. Nevertheless, the lack of skilled human resources and exports in small firms have caused the incompetence of in-house R\&D [Huang et al., 2010]. Size determines the choice of $R \& D$ in association with limited internally-generated funds that lead to the avoidance of risky investment and external collateral. Many studies have identified the existence of absorptive capacity within large firms rather than smaller ones in the capacity of human resources with regard to knowledge creation and exploitation of tacit knowledge in such variety of technology and management practices [Zhang et al., 2010]. The investment of explicit knowledge is required by exporter firms in order to develop a new product that fits the local market taste [Filatotchev \& Piesse, 2009]. In addition, innovation skills are determined by employees of educational level, training, and experience which subsequently influence the capability of knowledge absorptive capacity [Hitt et al., 2001]. The rule of thumb in conducting in-house $R \& D$ is the high initial investment [Rammer et al., 2009].

Nevertheless, several studies found that organisational structure of SMEs allows them to excel the large firms due to the fact that simple organisation is more efficient in adapting, internalising, crystallising, and disseminating new information which consequently leads to quicker and agile actions [Pelham, 2000]. For instance, limited investment to conduct in-house $R \& D$ causes SMEs to prefer acquisition of technological adoption as external R\&D while gaining external sources contribute positively to the firm's performance [Wang et al., 2014]. In the organisational routines, a few studies delineated 
that system-based response of learning on absorptive capacity controls the flow of information in the mechanism of knowledge acquisition, assimilation, transformation, and exploitation which in turn affects complex decision in the organisation [Fernhaber \& Patel, 2012] as well as the motivation of pursuing business opportunities [Engelen et al., 2014]. This discovery correlates with the empirical study conducted by Ahlin et al. (2014) where it has been suggested that absorptive capacity moderates the understanding mechanisms of the network for effective innovative performance in SMEs. Hence, the second the proposition is deduced: P2: Absorptive capacity has greater controls on the relationship of Entrepreneurial orientation and Non-R\&D Innovation

\section{The Mediating Role Of Non-R\&D Innovation}

In relation to the productivity growth of Organisation for Economic Co-operation and Development (OECD) industries, Griffith et al. (2000) emphasised that $R \& D$ has a significant role in stimulating innovation and transforming tacit knowledge into explicit knowledge particularly within the existence of absorptive capacity in technology transfer. This assertion is further supported by Moilanen et al. (2014) where it was described that the effort of acquiring the innovative performance with absorptive capacity assists SMEs of non-R\&D in forming the external knowledge explicitly. For instance, it has been reported that non-R\&D related activities in Nigeria's mining industry have contributed to the process and organisational innovation [Jegede et al., 2015]. Some studies argued implicitly that non-high-tech SMEs with a high entrepreneurial orientation through knowledge acquisition as well as $R \& D$ collaboration or collaboration in domestic and international markets enable to level up the capability of SMEs [Whittaker, 2016]. For example, the non-R\&D performance of non-hightech SMEs for product innovation is strengthened by international activities [Booltink \& SakaHelmhout, 2017]. Therefore, the third the proposition is deduced:

P3: High entrepreneurial orientation enable non$R \& D$ innovation facilitates innovation performance

\section{CONCEPTUAL FRAMEWORK}

Based on review of the extant literature, entrepreneurial orientation moderated by absorptive capacity is offered to strengthen firm performance of SMEs Germany in the turbulent environment [Engelen et al., 2014]. In the lowand medium-tech industries of Italy, entrepreneurial orientation is controlled by absorptive capacity for firm performance under knowledge based view [Sciascia et al., 2014]. This paper utilizes entrepreneurial orientation of innovativeness, proactiveness, risk taking and competitive aggressiveness to enable non $R \& D$ innovation (P1) controlled by absorptive capacity (P2) as ability of transforming external and internal knowledge into explicit knowledge. The trajectory is positioned to give impact on innovation performance in SMEs of low-tech industries (P3).

\section{IMPLICATIONS FOR FUTURE RESEARCH}

While this paper has provided the basic conceptual framework that could be useful to study non-R\&D innovation in the context of SMEs, considerable potential does exist for any improvements to be done in future research where the role played by the major constructs needs elaboration. As such, Table 1 has summarised the key findings with respect to SMEs in relation to the construct categories embedded in the conceptual framework. Future analysis of this framework in relation to its individual constructs would allow a better comprehension of the role played by non-R\&D innovation in SMEs and provide specific recommendations to improve SME performance. Additionally, contrasting the results of SMEs vis-à-vis larger organisations using the conceptual framework could be useful in this regard.

Non-R\&D or $R \& D$ is appointed to generate innovation activities for various range of products or quality improvement as well as to confirm the continuance of innovation activity in the firm. The propositions outlined in this study are intended to provide a substantial theoretical background to give direction in improving non- $R \& D$ innovation so that innovation performance is achieved. It is interesting where the support of $R \& D$ is vital in a turbulent change business environment while some firms with lack of technology prefer non$R \& D$ for their sustainability. It is also good to consider entrepreneurial orientation that is controlled by absorptive capacity in increasing innovation performance through non-R\&D innovation has not yet been established. The preliminary idea of this proposed model is connecting the entrepreneurial orientation to non$R \& D$ innovation for innovation performance. 
Nevertheless, the field of knowledge management has demonstrated that learning processes of SMEs to express tacit knowledge makes very little sense. Earlier studies evidenced that external knowledge access is strengthened by the capability of qualified human capital, referring to the level of education, training, and experiences as the key components. $R \& D$ function is presented in the $\mathrm{R} \& \mathrm{D}$ expenditure, workforce skills or marketing budgets as indicators of know-how regardless SMEs circumstances of non-technology [de Jong \& Fresser, 2010]. This condition implies that $R \& D$ function is sometimes perceived to generate innovation performance as $R \& D$ investment, $\mathrm{R} \& \mathrm{D}$ expenditures, and educational level that are otherwise oriented within knowledge management. For instance, Guo et al. (2017) suggested that the non-in-house $R \& D$ with the absorptive capacity provides an impact on innovation performance, particularly in the nontechnological firms of Chinese SMEs. Notwithstanding this finding, many researchers have revealed that SMEs with insufficient resources of such finance, skills, or information may cause less effect to the innovation performance, especially in the developing countries with a limited range of economic activities which subsequently lead to being more oriented within incremental change. Contrastingly, it has been recorded in the field of organisational approach that SMEs can excel the large firms in such short product lifecycle or compete with other counterparts as their simple organisational structure allows the shortening of decision-making processes; specific capabilities of SMEs can capture external information,

Table 1 Studies of Non-R\&D and Innovation Performance (Past 5 years)

\begin{tabular}{|c|c|c|}
\hline Author & Sample & Key findings \\
\hline $\begin{array}{l}\text { Lee and } \\
\text { Min } \\
(2015)\end{array}$ & $\begin{array}{l}\text { Using a sample of } \\
\text { Japanese } \\
\text { manufacturing } \\
\text { firms within the } \\
\text { period of 2001- } \\
2010\end{array}$ & $\begin{array}{l}\text { The findings } \\
\text { of this study } \\
\text { provide } \\
\text { valuable } \\
\text { insights and } \\
\text { fundamentals } \\
\text { of scientific } \\
\text { debate on } \\
\text { how firms to } \\
\text { engage } \\
\text { unique non- } \\
\text { R\&D } \\
\text { resources and } \\
\text { capabilities }\end{array}$ \\
\hline
\end{tabular}

transform, and realise it into new knowledge to take action more rapidly. There are a few studies that still consider the spirit of pursuing opportunity by defining the potential of businesses in relation to their the boldness of risktaking and endeavour to progress with their creativity in spite of the conventional technology; whereas it is in the strength of SMEs which differentiate the small firms from larger ones.

Moreover, in terms of the organisational responsiveness in the context of SMEs, the intention of capturing opportunities may increase non-R\&D activities as long as the capability of transforming external information into realised knowledge is well-developed [Liao et al., 2003]. This situation means that someone needs to direct the path of development non-R\&D function that is critical in sustaining firms' existence by resulting impact on product and process innovation in SMEs. It also means that the use of absorptive capacity as a control in knowledge acquisition and transformation must be made with the appropriate initiative support, and hence, the research in this area requires further development and clarity.

Future research should emphasise other dynamic capabilities as the core competence of SMEs in developing countries especially those that affect innovation performance to be a sustainable competitive advantage in the global business environment. Other capabilities might include strategic orientation and leadership in addition to the environmental characteristics that might be culture-based with regard to the reluctance of forward-moving technological adoption.

\section{for superior corporate environmenta 1 and performance.}

\begin{tabular}{|c|c|c|}
\hline $\begin{array}{l}\text { Guo, } \\
\text { Zheng, } \\
\text { and Liu } \\
(2017)\end{array}$ & $\begin{array}{l}\text { Using data of } 329 \\
\text { Chinese } \\
\text { manufacturing } \\
\text { SMEs }\end{array}$ & $\begin{array}{l}\text { These } \\
\text { findings } \\
\text { contribute to } \\
\text { understandin } \\
\mathrm{g} \text { the effects } \\
\text { of non-R\&D- } \\
\text { based } \\
\text { innovation } \\
\text { activities, } \\
\text { and the role }\end{array}$ \\
\hline
\end{tabular}




$\begin{array}{ll}\text { Yanting, } & \text { Using the } \\ \text { Xiao, and } & \text { quantitative data } \\ \text { Gang } & \text { of 506 SMEs in } \\ (2016) & \text { China, }\end{array}$

\author{
of SMEs' \\ absorptive \\ capacity in a \\ non-R\&D \\ context.
}

The results

provide

empirical

evidence that

SMEs'

dynamic

capabilities

mediate the

relationships

between

three kinds of

non-R\&D-

based

innovations,

namely

product and

service

customisatio

n, marketing

innovation

and

organizationa

1 innovation,

and business

performance.

Chen, Analysing data of

Heng, 269 IT

Tan, and

Lin

(2018)

(information

technology)

entrepreneurial

firms in China,

R\&D subsidy

has an inverted Ushape effect

$\begin{array}{ll}\begin{array}{l}\text { Hou, } \\ \text { Chen, }\end{array} & \begin{array}{l}\text { The empirical } \\ \text { results are } \\ \text { discussed }\end{array} \\ \text { Song, } & \text { according to the } \\ \text { and } & \text { panel data for } 30 \\ \text { (2018) } & \begin{array}{l}\text { provinces in } \\ \text { China concerning } \\ \text { the high-tech }\end{array}\end{array}$

industry.

performance

have a

significantly

different

"threshold

effect."

Hahn Using a sample of

(2018)

179 Dutch

companies that

was taken from

the European

Manufacturing

Survey conducted

by

FrauenhoferInstit

ut in 2015.

$\begin{array}{ll}\text { Lopez- } & \text { The model was } \\ \text { Rodrigue } & \text { estimated for a } \\ \mathrm{z} \text { and } & \text { sample of EU-26 } \\ \text { Martinez- } & \text { countries over the } \\ \text { Lopez } & \text { period 2004- } \\ \text { (2017) } & 2008 .\end{array}$

It was found that EDI and non-R\&D cooperation showed an autonomous positive effect on innovation performance.

The findings of the study revealed that the distinction between $R \& D$ and non-R\&D innovation activities were significant for innovation performance on IPO performance, while non$\mathrm{R} \& \mathrm{D}$ subsidy has a positive effect on IPO performance

Tsuji, The analytical Findings of Ueki, method divided the study Shigeno, sample firms indicated Idota, and categories, R\&D group into two that the Bunno namely, "the promoted (2018) R\&D group" and innovation "non-R\&D group."

Results argued that the mechanism of non-R\&D innovation activities on innovation by cross-

functional teams of production, engineering, and marketing and IT use, whereas the non-R\&D group 
promoted

product

innovation

\section{REFERENCES}

Adler, J.H. (1965). Absorptive capacity: The concept and its determinants. Brookings Institution, Washington.

Ahlin, B., Drnovšek, M., Hisrich, R. D. (2014). Exploring the moderating effects of absorptive capacity on the relationship between social networks and innovation. Journal of East European Management Studies, 19(2), 213-235.

Arora, P. (2011). Innovation in Indian firms: Evidence from the pilot national innovation survey. ASCI Journal of Management, 41(1), 75-90.

Arundel, A., Bordoy, C., Kanerva, M. (2008). Neglected innovators: How do innovative firms that do not perform R\&D innovate. Results of an analysis of the Innobarometer, 1-38.

Bala Subrahmanya, M. H. (2013). External support, innovation and economic performance: What firm level factors matter for high-tech SMEs? How? International Journal of Innovation Management, 17(05), 1-26.

Booltink, L. W., Saka-Helmhout, A. (2017). The effects of R\&D intensity and internationalization on the performance of non-high-tech SMEs. International Small Business Journal, 1-23.

Bouchard, V., Basso, O. (2011). Exploring the links between entrepreneurial orientation and intrapreneurship in SMEs. Journal of Small Business and Enterprise Development, 18(2), 219-231.

Burgelman, R.A. (1983). A process model of internal corporate venturing in the diversified major firm. Administrative Science Quarterly, 28(2), 223-44.

Chamelian, R. E. H. (2016). Applying a Marketing Approach to the Internationalization of a Technology SME: The Case of a French SaaS Vendor. Services Marketing Quarterly, 37(4), 255-271.

Chen, J., Heng, C. S., Tan, B. C., \& Lin, Z. (2018). The distinct signaling effects of $R \& D$ subsidy and non-R\&D subsidy on IPO performance of IT entrepreneurial firms in China. Research Policy, 47(1), 108120.

Cohen, W.M., Levinthal, D.A. (1989). Innovation and learning: the two faces of $\mathrm{R} \& \mathrm{D}$. The Economic Journal, 99(397), 569-596.

Cohen, W.M., Levinthal, D.A. (1990). Absorptive capacity: A new perspective on learning and innovation. Administrative Science Quarterly, 128-152.

Covin, J.G., Slevin, D.P. (1989). Strategic management of small firms in hostile and benign environments. Strategic Management Journal, 10(1), 75-87.

Covin, J.G., Slevin, D.P. (1991). A conceptual model of entrepreneurship as firm behavior. Entrepreneurship Theory and Practice, 16(1), 7-25.

Covin, J.G., Prescott, J.E., Slevin, D.P. (1990). The effects of technological sophistication on strategic profiles, structure and firm performance. Journal of Management Studies, 27(5), 485-510.

de Jong, J. P., Freel, M. (2010). Absorptive capacity and the reach of collaboration in high technology small firms. Research Policy, 39(1), 47-54.

Engelen, A., Kube, H., Schmidt, S., Flatten, T.C. (2014). Entrepreneurial orientation in turbulent environments: The moderating role of absorptive capacity. Research Policy, 43(8), 1353-1369.

Fernhaber, S.A., Patel, P.C. (2012). How do young firms manage product portfolio complexity? The role of absorptive capacity and ambidexterity. Strategic Management Journal, 33(13), 1516-1539.

Filatotchev I, Piesse J. (2009). R\&D, internationalization and growth of newly listed firms: European evidence. Journal of International Business Studies, 40(8): 1260-1276.

García-Sánchez, E., García-Morales, V., \& Martín-Rojas, R. (2018). Influence of technological assets on organizational performance through absorptive capacity, organizational innovation and internal labour flexibility. Sustainability, 10(3), 770.

Gomez-Mejia, L.R., Campbell, J.T., Martin, G., Hoskisson, R.E., Makri, M., Sirmon, D.G. (2014). Socioemotional wealth as a mixed gamble: Revisiting family firm $R \& D$ 
investments with the behavioral agency model. Entrepreneurship Theory and Practice, 38(6), 1351-1374.

Griffith,D.A.,Hu,M.Y.,Ryans,J.K.(2000).Process standardizationacrossintra-andinterculturalrelationships.JournalofInternationa lBusinessStudies,31(2), 303-325.

Guo, Y., Zheng, G., Liu, F. (2017). Non-R\&Dbased innovation activities and performance in Chinese SMEs: the role of absorptive capacity. Asian Journal of Technology Innovation, 1-19.

Hahn, I. (2018). The Role of Non-R\&D Driven Innovation. To what extent do non-R\&D practices enhance the innovation performance of a company? Thesis : Radboud University.

Hitt MA, Bierman L, Shimizu, K., Kochhar R. (2001). Direct and Moderating Effects of Human Capital on Strategy and Performance in Professional Service Firms: A Resource-Based Perspective. The Academy of Management Journal, 44(1): 13-28.

Hou, J., Chen, J., Song, H., \& Wang, G. (2018). Are Non-R\&D Innovation Activities Actually Effective for Innovation Sustainability? Empirical Study from Chinese High-Tech Industry. Sustainability, 11(1), 1-14.

Huang, C., Arundel, A., Hollanders, H. (2010). How firms innovate: $R \& D$, non- $R \& D$, and technology adoption. UNU-MERIT Working Paper Series.

Huda, M., Qodriah, S. L., Rismayadi, B., Hananto, A., Kardiyati, E. N., Ruskam, A., \& Nasir, B. M. (2019). Towards Cooperative With Competitive Alliance: Insights Into Performance Value in Social Entrepreneurship. In Creating Business Value and Competitive Advantage With Social Entrepreneurship (pp. 294-317): IGI Global

Intarakumnerd, P., Schiller, D. (2009). University-industry linkages in Thailand: Successes, failures, and lessons learned for other developing countries. Seoul Journal of Economics, 22(4), 551-589. From

Jegede, O.O., Ilori, M.O., Olorunfemi, M.O., Oluwale, B.A. (2015). Innovating in a resource based economy: Role of $R \& D$ and non-R\&D Activities. Proceedings of the OAU Faculty of Technology Conference. From
Kuratko, D.F., Morris, M.H. (2003). Corporate entrepreneurship: The dynamic strategy for 21 st century organizations. In Issues in Entrepeneurship (pp. 21-46). Emerald Group Publishing Limited.

Lasagni, A. (2012). How can external relationships enhance innovation in SMEs? New evidence for Europe. Journal of Small Business Management, 50(2), 310-339.

Lee, K.-H., \& Min, B. (2015). Green R\&D for eco-innovation and its impact on carbon emissions and firm performance. Journal of Cleaner Production, 108, 534-542.

Liao, J., Welsch, H., Stoica, M. (2003). Organizational absorptive capacity and responsiveness: an empirical investigation of growth-oriented SMEs. Entrepreneurship Theory and Practice, 28(1), 63-85.

Lopez-Rodriguez, J., Martinez-Lopez, D. (2017). Looking beyond the R\&D effects on innovation: The contribution of non-R\&D activities to total factor productivity growth in the EU. Structural Change and Economic Dynamics, 40, 37-45.

Lumpkin, G. T., Dess, G. (1996). Clarifying the entrepreneurial orientation construct and linking it to performance. Academy of Management Review, 21(1), 135-172.

Lumpkin, G. T., Dess, G. G. (2001). Linking two dimensions of entrepreneurial orientation to firm performance: the moderating role of environment and industry life cycle. Journal of Business Venturing, 16, 429451.

Martínez-Román, J. A., Romero, I. (2017). Determinants of innovativeness in SMEs: disentangling core innovation and technology adoption capabilities. Review of Managerial Science, 11(3), 543-569. .

Miller, D. (1983). The correlates of entrepreneurship in three types of firms. Management Science, 29(7), 770-791. Miller, D. Toulouse, J. M. (1986). Strategy, structure, CEO personality and performance in small firms. American Journal of Small Business, 10(3), 47-62.

Moilanen, M., Østbye, S., Woll, K. (2014). NonR\&D SMEs: external knowledge, absorptive capacity and product innovation. Small Business Economics, 43(2), 447-462. .

OECD, 2005. Oslo Manual, OECD, Paris.

Parkman, I.D., Holloway, S.S., Sebastiao, H. (2012). Creative industries: aligning 
entrepreneurial orientation and innovation capacity. Journal of Research in Marketing and Entrepreneurship, 14(1), 95-114.

Pelham, A.M. (2000). Market orientation and other potential influences on performance in small and medium-sized manufacturing firms. Journal of Small Business Management, 38(1), 48.

Pinchot, G. (1985). How intrapreneurs innovate. Management Today, December, 54-63.

Rammer, C, Czarnitzki, D, Spielkamp, A. (2009). Innovation success of non-R\&Dperformers: substituting technology by management in SMEs. Small Business Economics, 33(1): 35-58.

Robertson, P.L., Patel, P.R. (2007). New wine in old bottles: technological diffusion in developed economies. Research Policy, 36 (5), 708-721.

Santamaría, L., Nieto, M. J., Barge-Gil, A. (2009). Beyond formal R\&D: Taking advantage of other sources of innovation in low-and medium-technology industries. Research Policy, 38(3), 507-517.

Sciascia, S., D’oria, L., Bruni, M., Larrañeta, B. (2014). Entrepreneurial Orientation in lowand medium-tech industries: The need for Absorptive Capacity to increase performance. European Management Journal, 32(5), 761-769.

Stam, W., Elfring, T. (2008). Entrepreneurial orientation and new venture performance: The moderating role of intra-and extraindustry social capital. Academy of Management Journal, 51(1), 97-111.

Suyanto, A.H..P. (2014). The Impact of Entrepreneurship Orientation, Human Capital, and Social Capital on Innovation Success of Small Firms in East Java. Jurnal Manajemen Teknologi, 13(1), 117-125.

Teece, D., Pisano, G. Shuen, A. (1997). Dynamic capabilities and strategic management. Strategic Management Journal, 18, 7, 537556.

Tsuji, M., Ueki, Y., Shigeno, H., Idota, H., \& Bunno, T. (2018). R\&D and non-R\&D in the innovation process among firms in ASEAN countries: Based on firm-level survey data. European Journal of Management and Business Economics, 27(2), 198-214.

Yanting, G., Xiao, C., \& Gang, Z. (2016). How do $n o n-R \& D$-based innovations affect
SMEs' performance? The mediating role of dynamic capabilities. Paper presented at the 2016 Portland International Conference on Management of Engineering and Technology (PICMET).

Venkatraman, N. (1989). Strategic Orientation of Business Enterprises: The Construct, Dimensionality, and Measurement. Management Science, 35(8), 942-962.

Wang, Z., Wang, N., Liang, H. (2014). Knowledge sharing, intellectual capital and firm performance. Management Decision, 52(2), 230-258.

Whittaker, D.H. (2016). Assembling capabilities for innovation: Evidence from New Zealand SMEs. International Small Business Journal, 34(1), 123-143.

Wiklund, J., Shepherd, D. (2005). Entrepreneurial orientation and small business performance: a configurational approach. Journal of Business Venturing. 20(1), 7189.

Zahra, S.A., George, G. (2002). Absorptive capacity: A review, reconceptualization, and extension. Academy of Management Review, 27(2), 185-203. Zahra, S., Covin, J. G. (1995), Contextual influences on the corporate entrepreneurship-performance relationship: A longitudinal analysis. Journal of Business Venturing, 10, 43-58.

Zahra, S.A. (1996). Technology Strategy and Financial Performance: Examining the Moderating Role of the Firm's competitive Environment. Journal of Business Venturing, 11, 189-219.

Zehir, C., Can, E., Karaboga, T. (2015). Linking entrepreneurial orientation to firm performance: the role of differentiation strategy and innovation performance. Procedia-Social and Behavioral Sciences, 210, 358-367.

Zhang, Y., Li, H., Li, Y., Zhou, L.A. (2010). FDI spillovers in an emerging market: the role of foreign firms' country origin diversity and domestic firms' absorptive capacity. Strategic Management Journal, 31(9), 969989. 